\title{
Pharmacokinetics of Furosemide Urinary Elimination by Nephrotic Children
}

\author{
JOZEF PRANDOTA
}

J. Korczak Memorial Children's Hospital, Wroclaw, Poland

\begin{abstract}
Summary
Single doses of $2 \mathrm{mg} / \mathrm{kg}$ of furosemide (F) were given postprandially as tablets to 17 steroid-responsive nephrotic syndrome (NS) patients, 2.5-15 years old, and seven control children requiring $F$ therapy. One-half, 1 , and $2 \mathrm{~h}$ after administration, $\mathrm{F}$ absorption rate, calculated from the drug urinary excretion data, was significantly more rapid in the NS patients compared to that in the controls. Bioavailability of $\mathrm{F}$ in the nephrotic children averaged $58.8 \%$ indicating that the gastrointestinal absorption of the drug was unaffected by the disease and by the age of the patients. The first pass effect of $\mathrm{F}$ was $24 \%$ of the administered dose. The elimination half-life of $\mathrm{F}$, calculated from the drug urinary excretion data in the NS patients was $2.06 \pm 0.96 \mathrm{~h}$ (mean \pm SD), whereas in the control children, it was $2.14 \pm 0.69 \mathrm{~h}$. There seems to be no relationship between $F$ elimination half-life and the serum albumin concentration in the NS patients. Also, no correlation was found between the amount of $F(\mathrm{mg})$ excreted in urine during 2 or $6 \mathrm{~h}$ after administration (the time of complete absorption of $F$ from the gastrointestinal tract, and the time of the drug diuretic effect, respectively) and the serum albumin concentration in the NS patients. Moreover, no significant difference in the cumulative F urinary excretion was found between both groups of children. The data indicate that factors in addition to serum albumin concentration play a role in the elimination kinetics of $F$ in nephrotic children.
\end{abstract}

\section{Speculation}

In children with steroid-responsive nephrotic syndrome furosemide administered orally at a dose of $2 \mathrm{mg} / \mathrm{kg}$ of actual weight (plus edema), is absorbed from the gastrointestinal tract significantly more rapidly than in the control group of patients. After a 2-wk course of treatment with prednisone, the absorption rate of the drug is slowed down. It is suggested that this is caused by a larger extracellular compartment in an edematous nephrotic into which the furosemide may move.

\section{Abbreviations}

BUN, blood urea nitrogen

F, furosemide

NS, nephrotic syndrome

The distribution in the body, rate of metabolism, elimination, biologic effect, and toxicity of many acidic drugs can be greatly influenced by their binding to plasma and tissue proteins $(4,10$, $18,31)$. On the other hand, although binding could be a factor, it probably is not involved in the rate of the oral absorption-determining step (4). Also, no information as yet is available on the influence of binding on the bioavailability of drugs.

The nephrotic syndrome (NS) is a disorder characterized by increased glomerular permeability to plasma proteins (chiefly albumin), with subsequent hypoproteinemia (primarily hypoalbuminemia) and dysproteinemia. It is generally held that there is identity between the urinary and serum albumin in both the normal and nephrotic subjects, and that there is no immunochemical and electrophoretic alteration of the albumin molecule $(7,8$, 29 ), and also no apparent change in its binding characteristics (10). Some authors (10) believe that all changes in the pharmacokinetics of highly protein bound drugs in nephrotic patients are solely a result of a decrease in protein concentration.

Furosemide $(\mathrm{F})$, a potent diuretic often used in children with edema developing in the course of NS, is a weak organic acid with a pKa 3.6, highly bound to human albumin $(23,24)$. Protein binding of $F$ in the plasma of nephrotic children correlated with their respective plasma albumin concentrations, the unbound fraction of the drug being increased by more than $100 \%$ when the albumin concentration in plasma was lower than $2 \mathrm{~g}$ per $100 \mathrm{ml}$ (23). Despite its widespread use, data relevant to $\mathrm{F}$ absorption and elimination after oral administration in patients with the NS is not available. Besides attempting to develop such a data base, the purpose of this study also was to establish the role of the plasma albumin concentration in the drug's urinary excretion kinetics.

\section{PATIENTS AND METHODS}

Subjects. Seventeen patients with steroid-responsive NS [8 wk of treatment was the basis for differentiating responders and nonresponders to prednisone therapy (29), ranging in age from 2.5-15 years, were studied at the Children's Hospital of Wroclaw. The diagnosis was based on clinical history and manifestations, hypoproteinemia and dysproteinemia, hyperlipemia, and urinary protein excretion. Some of the clinical data and biochemical characteristics of the patients are listed in Table 1. BUN and serum creatinine of the patients studied were normal except for patient 3 who had a BUN of $23 \mathrm{mg} / 100 \mathrm{ml}$ and a serum creatinine level of $1.26 \mathrm{mg} / 100 \mathrm{ml}$, and for patient 17 who had a BUN of 10 $\mathrm{mg} / 100 \mathrm{ml}$ and a serum creatinine of $1.17 \mathrm{mg} / 100 \mathrm{ml}$. The control group of children consisted of seven subjects, 5-12 years old (three girls, four boys), with pyelonephritis and mild hypertension. These children had normal BUN and serum creatinine levels, and their mean serum albumin concentration was $4.3 \mathrm{~g}$ per $100 \mathrm{ml}$ (ranging from $2.6-5.9 \mathrm{~g} / 100 \mathrm{ml}$ ). All children received $\mathrm{F}$ because of clinical indications. In four of the nephrotic children (patients $4 a, 5 a, 7 a$, and $8 \mathrm{a}$ ), the study was performed twice, the second investigation being carried out after an approximate 2 -wk course of treatment with a $2 \mathrm{mg} / \mathrm{kg} /$ day dose of prednisone. Patient $15 \mathrm{~b}$ had the second study of $F$ kinetics performed during the recurrence of the disease. Neither study group was confined to bed during the study.

Study procedure. F (Lasix) was given as a tablet in a single 2 $\mathrm{mg} / \mathrm{kg}$ of actual weight (plus edema) dose (except for patients 1 and 2) after a standard breakfast. The patients were not fasting at the time of drug administration because earlier studies in adults (17) have shown that dosage form of $F$ and ingestion of food has no effect on the bioavailability and the diuretic response to $F$. On the day of the investigation all patients were under their usual daily treatment schedule so that the administration of $F$ did not affect their therapeutic regimen. A few (usually three) days later eight subjects (patients $1,2,3,4,5,6,9$, and 11 ) also received $F$ in 
Table 1. Clinical data of nephrotic syndrome patients

\begin{tabular}{|c|c|c|c|c|c|c|}
\hline \multirow[b]{2}{*}{$\begin{array}{l}\text { Case } \\
\text { No. }\end{array}$} & \multirow[b]{2}{*}{$\begin{array}{l}\text { Age } \\
\text { (yr) }\end{array}$} & \multirow[b]{2}{*}{$\begin{array}{l}\text { Sex, } \\
\text { weight } \\
(\mathrm{kg})\end{array}$} & \multicolumn{2}{|c|}{ Serum } & \multirow[b]{2}{*}{$\begin{array}{c}\text { Urine } \\
\text { protein } \\
(\mathrm{g} / 24 \mathrm{~h})\end{array}$} & \multirow[b]{2}{*}{$\begin{array}{l}\text { Medication } \\
\text { and daily } \\
\text { dose }^{1}\end{array}$} \\
\hline & & & $\begin{array}{l}\text { albumin/globulin } \\
(\mathrm{g} / \mathrm{dI})\end{array}$ & $\begin{array}{l}\text { cholesterol } \\
(\mathrm{mg} / \mathrm{dl})\end{array}$ & & \\
\hline 1 & $46 / 12$ & $\begin{array}{l}\mathrm{M} \\
(18.9)\end{array}$ & $0.76 / 2.5$ & 310 & 16.1 & $\begin{array}{l}\mathrm{P}, 1 \mathrm{mg} / \mathrm{kg} \\
\mathrm{C}, 2 \mathrm{~g}\end{array}$ \\
\hline 2 & $61 / 12$ & $\begin{array}{l}M \\
(23.4)\end{array}$ & $0.97 / 2.32$ & 438 & 1.25 & $\begin{array}{l}\mathrm{P}, 1 \mathrm{mg} / \mathrm{kg} ; \mathrm{C}, \\
2 \mathrm{~g} ; \mathrm{AMI}, 0.2 \mathrm{~g}\end{array}$ \\
\hline 3 & 3 & $\begin{array}{l}\mathrm{F} \\
(18.4)\end{array}$ & $1.26 / 2.01$ & 605 & 2.32 & $\begin{array}{l}\mathrm{P}, 2 \mathrm{mg} / \mathrm{kg} ; \mathrm{PP} \\
0.9 \text { m.u.; } \mathrm{S}, 12 \mathrm{mg}\end{array}$ \\
\hline 4 & $36 / 12$ & $\begin{array}{l}M \\
(16.5)\end{array}$ & $1.59 / 2.81$ & 420 & 1.2 & PP, 2.4 m.u. \\
\hline 5 & $31 / 12$ & $\begin{array}{l}\mathrm{M} \\
(18.4)\end{array}$ & $1.66 / 1.98$ & & 10.3 & PP, 1.2 m.u. \\
\hline 6 & 5 & $\begin{array}{l}F \\
(25)\end{array}$ & $1.73 / 2.27$ & 526 & $4.7 / 16 \mathrm{~h}$ & $\begin{array}{l}\mathrm{P}, 2 \mathrm{mg} / \mathrm{kg} \\
\text { PP, } 1.2 \mathrm{~m} . \mathrm{u} .\end{array}$ \\
\hline 7 & $43 / 12$ & $\begin{array}{l}\mathrm{M} \\
(18.3)\end{array}$ & $1.78 / 2.22$ & 390 & 4.1 & $\begin{array}{l}\mathrm{P}, 0.5 \mathrm{mg} / \mathrm{kg} \text { on alter- } \\
\text { nate days }\end{array}$ \\
\hline 8 & $1410 / 12$ & $\begin{array}{l}F \\
(56.9)\end{array}$ & $1.96 / 2.04$ & 389 & 14.7 & BP, 1.2 m.u. \\
\hline 9 & $210 / 12$ & $\begin{array}{l}M \\
(19.2)\end{array}$ & $2.1 / 1.9$ & 511 & & $\begin{array}{l}\mathrm{P}, 2 \mathrm{mg} / \mathrm{kg} \\
\text { PP, } 0.6 \mathrm{m.u} .\end{array}$ \\
\hline 10 & $51 / 12$ & $\begin{array}{l}F \\
(19.2)\end{array}$ & $2.13 / 1.87$ & 320 & 16 & $\begin{array}{l}\mathrm{P}, 2 \mathrm{mg} / \mathrm{kg} ; \mathrm{AMP} \\
1 \mathrm{~g} ; \mathrm{S}, 20 \mathrm{mg}\end{array}$ \\
\hline 11 & $35 / 12$ & $\begin{array}{l}F \\
(17.6)\end{array}$ & $2.24 / 2.9$ & 552 & $3 / 12 \mathrm{~h}$ & $\begin{array}{l}\mathrm{P}, 2 \mathrm{mg} / \mathrm{kg} \\
\mathrm{S}, 12.5 \mathrm{mg}\end{array}$ \\
\hline 12 & $46 / 12$ & $\begin{array}{l}M \\
(19.6)\end{array}$ & $2.39 / 2.39$ & 358 & 1.07 & $\mathrm{P}, 1 \mathrm{mg} / \mathrm{kg}$ \\
\hline 13 & $27 / 12$ & $\begin{array}{l}F \\
(16.9)\end{array}$ & $2.69 / 2.19$ & 252 & 0.37 & $\begin{array}{l}\mathrm{P}, 2 \mathrm{mg} / \mathrm{kg} \\
\mathrm{PP}, 0.6 \mathrm{~m} . \mathrm{u} .\end{array}$ \\
\hline 14 & $68 / 12$ & $\begin{array}{l}F \\
(28.7)\end{array}$ & $3.02 / 2.5$ & 262 & 0.39 & $\begin{array}{l}\mathrm{P}, 0.5 \mathrm{mg} / \mathrm{kg} \\
\mathrm{G}, 60 \mathrm{mg}\end{array}$ \\
\hline 15 & $411 / 12$ & $\begin{array}{l}F \\
(22.4)\end{array}$ & $3.07 / 2.64$ & 230 & 19.5 & $\mathrm{P}, 1 \mathrm{mg} / \mathrm{kg}$ \\
\hline 16 & $67 / 12$ & $\begin{array}{l}F \\
(29)\end{array}$ & $3.19 / 2.71$ & 195 & 3.21 & $\begin{array}{l}\mathrm{P}, 1 \mathrm{mg} / \mathrm{kg} \\
\mathrm{N}, 150 \mathrm{mg}\end{array}$ \\
\hline 17 & $69 / 12$ & $\begin{array}{l}F \\
(26.7)\end{array}$ & $3.49 / 2.77$ & 210 & 3.21 & \\
\hline
\end{tabular}

\footnotetext{
' $\mathrm{P}$, prednisone; AMP, ampicillin; BP, benzathine penicillin; $\mathrm{C}$, cloxacillin; $\mathrm{G}$, gentamicin; PP, procaine penicillin; $\mathrm{N}$, nitrofurantoin; AMI,
} aminophylline; S, spironolactone; and m.u., million units.

an intravenous injection (26), which permitted the calculation of bioavailability of the drug. At the time of this investigation, weight of the patients changed by $-5.5,-0.5,0,+13,+0.5,+4,+12.2$, and $-2.5 \%$, respectively.

Urine was collected by spontaneous voiding before administration of $\mathrm{F}$ and at hourly intervals for $6 \mathrm{~h}$, and then 6-8, 8-12, and $12-24 \mathrm{~h}$ (if possible) after $\mathrm{F}$ administration. The volume of each urine sample was measured and aliquot taken and stored in the dark at $-20^{\circ} \mathrm{C}$ for a few wk until assayed. An effort was made to prevent undue exposure of urine samples to light to prevent degradation of $F$. The urinary concentration of $F$ was determined in duplicate by the fluorimetric method of Häussler and Hajdú (11) with the modification of Lucas et al. (19), using blanks prepared from urine samples obtained before the drug was administered. The sensitivity of the method is $0.5 \mu \mathrm{g} / \mathrm{ml}$, and the calibration curve, derived from adding known amounts of $F$ to urine and analyzing the samples was linear up to $50 \mu \mathrm{g}$ per $\mathrm{ml}$ This method, however, is not specific for detection of the parent drug alone, because a small portion of the major metabolites of $F$, 4-chloro-5-sulfamoylanthranilic acid (CSA), and F glucuronide, will also be extracted with the drug $(1,27,30)$. Nevertheless, with use of this method we had previously shown $(25,34)$ a highly significant positive correlation between urinary $F$ excretion rate and urine flow in children; it suggests that $\mathrm{F}$ and its metabolites participate in the drug diuretic effect. It is known that CSA is onefourth as potent diuretic as the parent substance (30).
Kinetic data analysis. The drug absorption rate, its biologic halflife, and elimination rate constant were calculated with the use of the noninvasive method based on $F$ cumulative urinary excretion data $(20,21)$. For this purpose the following formulas were used:

$$
\frac{\mathrm{dA}}{\mathrm{dt}}=\frac{\mathrm{l}}{\mathrm{f}}\left(\frac{\mathrm{l}}{\mathrm{k}_{\mathrm{el}}} \frac{\mathrm{d}^{2} \mathrm{X}_{\mathrm{u}}}{\mathrm{dt}^{2}}+\frac{\mathrm{d} \mathrm{X}_{\mathrm{u}}}{\mathrm{dt}}\right)
$$

where $f$ is the fraction of the amount absorbed which is eventually excreted with urine, $\mathrm{dX}_{\mathrm{u}} / \mathrm{dt}$ is the excretion rate and $\mathrm{d}^{2} \mathrm{X}_{\mathrm{u}} / \mathrm{dt}^{2}$ is the derivative of the excretion rate. This equation may be integrated between the limits of $t=0$ and $t=T$ to obtain:

$$
A_{T}(f)=\frac{1}{k_{e l}}+\frac{d X_{u}}{d t} X_{u}
$$

where $X_{u}$ is the cumulative amount of drug excreted in the urine to time $\mathrm{T}$.

The disposition of $\mathrm{F}$ in children and adults has been analyzed by either a one or two-compartment open model $(1,2,3,17,19$, 22 ). In the present studies the one-compartment model was used for three reasons: (1) semilogarithmic plots of the $F$ urinary excretion rate profiles were compatible with a one-compartment model (Fig. 1), as the drug plasma disappearance curves obtained in some normal adults (3), patients with acute pulmonary edema (22), and in newborn infants (2) after intravenous administration of $F$; (2) The validity of the one-compartment model is supported 


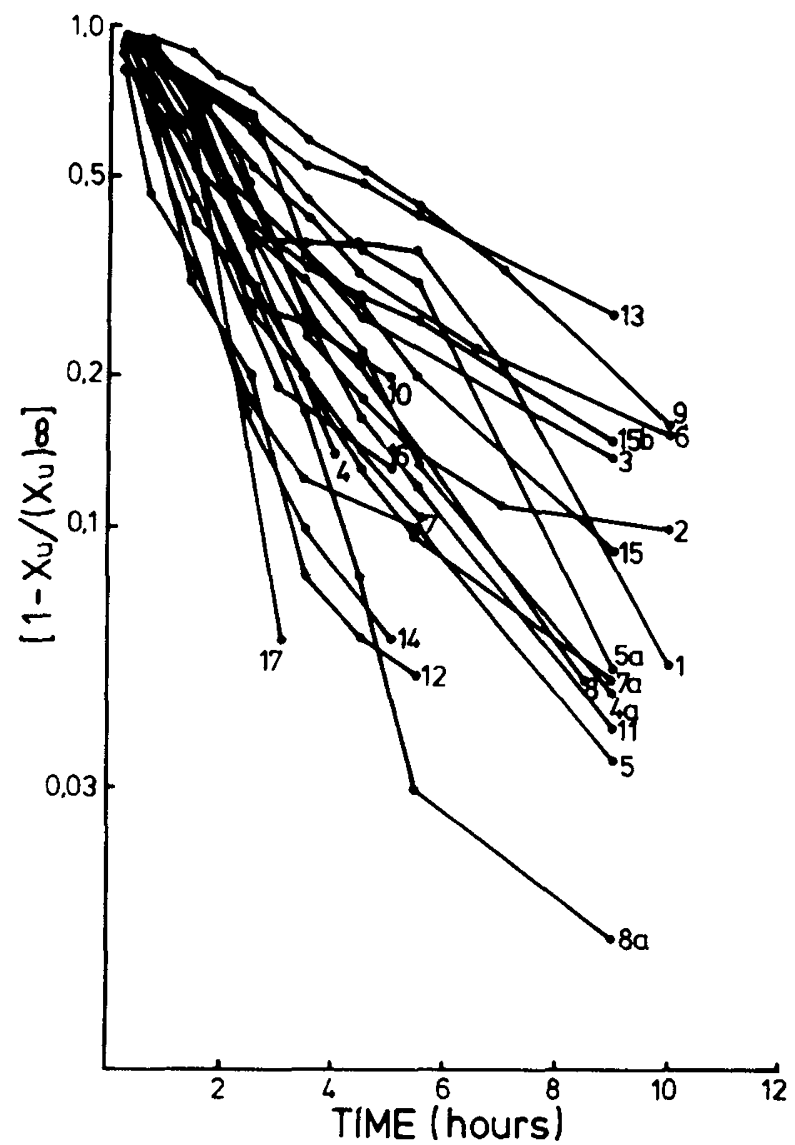

Fig. 1. Semilogarithmic plot of $\left[1-\mathrm{X}_{u} /\left(\mathrm{X}_{\mathrm{u}}\right)_{\infty}\right]$ versus time as determined from urine data of the studied nephrotic patients after oral administration of $2 \mathrm{mg} / \mathrm{kg}$ furosemide (further explanation see in the text).

by the fact that the measured values and the calculated curves fit well (see the correlation and regression coefficients in Table 2) which permits this method of mathematic analysis to be regarded as satisfactory $(15,32)$; and (3) Urine was collected for a period corresponding to more than 10 half-lives of $F$, which according to Wagner (33) is sufficient to estimate $k_{\mathrm{el}}$ from the slope of the terminal (linear) section of the plot. This slope was determined by the method of least squares. The urinary elimination half-life of $F$ was calculated with the use of the following expression $(6,15$, 32):

$$
\log \left(1-\frac{X_{u}}{\left(X_{u}\right)_{\infty}}\right)=-k_{\mathrm{el}} \mathrm{t} / 2.303
$$

where $\left(X_{u}\right)_{\infty}$ represents the amount of drug ultimately excreted in the urine. The elimination $t^{1 / 2}$ s of $F$, determined with the use of this method are in agreement with the $t \frac{1}{2} \mathrm{~S}$ of the drug calculated from $F$ plasma concentration decline curve in children $4 \% 12$ to $153 / 12$ years old with acute glomerulonephritis (27), and with the data found in healthy adults by Rupp (30) in regard to so called segment " $c$ " of the drug plasma concentration decline curve, as well as with the data reported by Andreasen and Mikkelsen (1), and Beerman et al. (3).

In all patients, the behaviour of the $F$ urinary excretion rate profile exhibited monophasic characteristics. In patients 5 and $15 \mathrm{~b}$, the curves could also be described by the two-compartment open model.

The bioavailability of $F$, i.e., the amount of the drug available to the renal tubule, was calculated from F 24-h urinary excretion data as follows:

$$
\% \text { Availability }=\frac{\left(\mathrm{X}_{\mathrm{u}}\right)_{\infty} \text { oral }}{\left(\mathrm{X}_{\mathrm{u}}\right)_{\infty} \mathrm{IV}} \times 100
$$

where $\left(\mathrm{X}_{\mathrm{u}}\right)_{\infty}$ oral or IV is the total amount of $\mathrm{F}$ excreted in urine during the $24 \mathrm{~h}$ after oral or intravenous administration of $2 \mathrm{mg} /$ $\mathrm{kg}$ dose of the drug because preliminary studies have shown that after that time $F$ was excreted in urine in insignificant amounts.

\section{RESULTS}

$F$ absorption. In 12 out of 17 of the studies performed in the nephrotic children, the amount of $F$ finally excreted in urine during $24 \mathrm{~h}$ was calculated to be completely absorbed from the gastrointestinal tract $2 \mathrm{~h}$ after the drug administration. In the group of control children, on the other hand, three out of seven subjects completely absorbed $\mathrm{F}$ by that time. The absorption rate of the drug, $0.5,1$ and $2 \mathrm{~h}$ after administration, was found to be significantly more rapid in the nephrotic patients than in the group of control children (Table 2). No relationship was found between the serum albumin concentration of the nephrotic children and the amount of unabsorbed $F$ half and one hour after the drug was administered.

In patients $4 a, 5 a, 7 a$, and $8 a$, who received $F$ twice, the second time after an approximate 2-wk course of treatment with prednisone, the absorption rate of the diuretic administered after such treatment was slower than the absorption rate during the acute phase of the disease. Similarly, in patient $15 \mathrm{~b}$, who had a recurrence of the disease, $F$ was absorbed more quickly then during the remission phase when the dose of prednisone was $1 \mathrm{mg} / \mathrm{kg} /$ day (Table 2).

During the $24 \mathrm{~h}$ after oral administration, the nephrotic children excreted in urine $35.05 \pm 17.8 \%$ (mean \pm S.D.) of the administered dose of $F$ compared to $59.6 \pm 22.3 \%$ after intravenous injection. Thus, the bioavailability of $\mathrm{F}$ in the nephrotic children was $58.8 \%$ of the given dose. The first pass effect of $F$ equals $24 \%$ of the dose difference.

Kinetics of $F$ elimination in urine. Figs. 1 and 2 illustrate the semilogarithmic plots of $\left(1-\mathrm{X}_{\mathrm{u}} /\left(\mathrm{X}_{\mathrm{u}}\right)_{\infty}\right.$ versus time from which the urinary elimination $t^{1 / 2} \mathrm{~S}$ of $\mathrm{F}$ of the studied children were determined. The biologic half-lives and elimination rate constants of the drug in the nephrotic children and the control patients are listed in Table 2 . The average urinary $F t^{1 / 2}$ in the NS patients was $2.06 \mathrm{hr}$, whereas in the controls $\mathrm{F}$ averaged $2.14 \mathrm{hr}$. In the group of patients receiving $F$ twice, the second time after a treatment with prednisone, a comparison of the $t^{1} / 2$ values of $F$ found after the first and second administration, showed that this parameter in patients $4 \mathrm{a}$ and $5 \mathrm{a}$ increased by 24 and $165 \%$ respectively, whereas that of patients $7 \mathrm{a}$ and $8 \mathrm{a}$ decreased by 32 and $53 \%$, respectively. The serum albumin concentrations in those patients at the time of the second investigation were the following: $3.17,2.61,3.25$, and $2.5 \mathrm{~g}$ per $100 \mathrm{ml}$, respectively (this data may be contrasted to that obtained in the Ist investigation by referring to Table 1). Patient $15 \mathrm{~b}$, who suffered a relapse of the disease, had no change in the $t \frac{1}{2}$ of $F$ when measured at the time of the first and second manifestations of the syndrome (at the time of the second study the serum albumin concentration in this patient was $3.07 \mathrm{~g}$ per $100 \mathrm{ml}$ ).

The drug excretion rate profile in Pts 5 and $15 \mathrm{~b}$ were also analyzed using a two-compartment open model, which showed the respective urinary $F$ half-lives and elimination rate constants to be the following:

$$
\begin{gathered}
\text { Patient 5:F t1/2/ }=0.34 \mathrm{~h}, \mathrm{k}_{\text {el } \alpha}=2.049 \mathrm{~h}^{-1} ; \mathrm{t}^{1 / 2 / 2 \beta}=2.49 \mathrm{~h}, \mathrm{k}_{\mathrm{el} \beta}= \\
0.278 \mathrm{~h}^{-1}, \mathrm{c}=0.997, \mathrm{~d}=0.998,
\end{gathered}
$$

Patient 15b:F t $1 / 2_{\alpha}=0.86 \mathrm{~h}, \mathrm{k}_{\mathrm{el} \alpha}=0.804 \mathrm{~h}^{-1} ; \mathrm{t}^{\mathrm{t} / 2 \beta}=6.73 \mathrm{~h}, \mathrm{k}_{\mathrm{el} \beta}=$ $0.103 \mathrm{~h}^{-1}, \mathrm{c}=0.993, \mathrm{~d}=1.000$

No correlation was found between the serum albumin concentration in the NS children and their respective urinary $F$ elimination half-lives. Also, no relationship was found between the serum albumin concentration of the nephrotics and the amount of $F$ excreted in the urine collected for $2 \mathrm{~h}$ (the time necessary for 
Table 2. Pharmacokinetic parameters for $F$ in nephrotic syndrome patients and control subjects

\begin{tabular}{|c|c|c|c|c|c|c|c|c|}
\hline \multirow{2}{*}{$\begin{array}{l}\text { Case } \\
\text { No. }\end{array}$} & \multirow{2}{*}{$\begin{array}{l}\text { Dose } \\
(\mathrm{mg})\end{array}$} & \multirow{2}{*}{$\begin{array}{l}\mathrm{t}^{1 / 2} \\
\text { (h) }\end{array}$} & \multirow{2}{*}{$\begin{array}{c}k_{\text {el }} \\
\left(h^{-1}\right)\end{array}$} & \multirow[b]{2}{*}{$c^{1}$} & \multirow[b]{2}{*}{$d^{\prime}$} & \multicolumn{3}{|c|}{$\%$ unabsorbed after } \\
\hline & & & & & & $0.5 \mathrm{~h}$ & $1 \mathrm{~h}$ & $2 \mathrm{~h}$ \\
\hline \multicolumn{9}{|c|}{ Nephrotic children } \\
\hline 1 & 60 & 2.8 & 0.247 & 0.966 & 0.989 & 43.3 & 42.8 & 0 \\
\hline 2 & 60 & 1.78 & 0.39 & 0.991 & 0.972 & 76.2 & 36.1 & 0.4 \\
\hline 3 & 40 & 2.62 & 0.265 & 0.98 & 0.997 & 42.8 & 45.1 & 39.1 \\
\hline 4 & 33 & 1.56 & 0.443 & 0.993 & 1.033 & 41.1 & 17.4 & 18.7 \\
\hline 5 & 36 & 1.09 & 0.636 & 0.981 & 0.929 & 0 & & \\
\hline 6 & 50 & 2.75 & 0.252 & 0.991 & 0.951 & 86 & 19.3 & 0 \\
\hline 7 & 37 & 2.09 & 0.332 & 0.999 & 1.005 & 8.8 & 0 & \\
\hline 8 & 114 & 1.95 & 0.355 & 0.99 & 1.006 & 33.3 & 9.5 & 0 \\
\hline 9 & 40 & 4.08 & 0.17 & 0.995 & 1.010 & 33.6 & 0 & \\
\hline 10 & 40 & 1.76 & 0.393 & 0.985 & 0.969 & 10 & 0 & \\
\hline 11 & 35 & 1.61 & 0.431 & 0.994 & 1.002 & & $62^{4}$ & 0 \\
\hline 12 & 40 & 0.99 & 0.702 & 0.995 & 0.984 & 36.4 & 12.8 & 0 \\
\hline 13 & 34 & 4.35 & 0.159 & 0.992 & 0.985 & 60 & 8.9 & \\
\hline 14 & 58 & 0.91 & 0.758 & 0.997 & 0.977 & 45.7 & 11.7 & 0 \\
\hline 15 & 45 & 2.28 & 0.304 & 0.997 & 0.994 & 71 & 18 & 0 \\
\hline 16 & 58 & 1.2 & 0.577 & 0.995 & 0.959 & 44.9 & 7.7 & 0 \\
\hline 17 & 54 & 1.3 & 0.533 & 0.959 & 1.094 & 73.2 & 45.7 & 11.7 \\
\hline Mean & & 2.06 & 0.40 & & & $44.1^{5}$ & $19.8^{5}$ & $4.37^{5}$ \\
\hline S.D. & & 0.96 & 0.023 & & & 24.05 & 18.68 & 10.5 \\
\hline $4^{2}$ & 36 & 1.94 & 0.387 & 0.991 & 1.013 & 89 & 40.5 & 1.8 \\
\hline $5^{2}$ & 30 & 2.89 & 0.24 & 0.992 & 1.031 & 71 & 45.9 & 11.4 \\
\hline $7^{2}$ & 40 & 1.43 & 0.486 & 0.988 & 0.987 & 76.1 & 35 & 0 \\
\hline $8^{2}$ & 100 & 0.91 & 0.765 & 0.989 & 0.998 & 66.3 & 22.5 & 0 \\
\hline $15^{3}$ & 46 & 2.34 & 0.296 & 0.973 & 0.937 & 36.2 & 0 & \\
\hline \multicolumn{9}{|c|}{ Control subjects } \\
\hline 1 & 55 & 2.08 & 0.334 & 0.995 & 0.984 & 71 & 22.4 & 0 \\
\hline 2 & 45 & 1.61 & 0.43 & 0.995 & 1.010 & 80.6 & 34.1 & 3 \\
\hline 3 & 40 & 2.44 & 0.284 & 0.947 & 1.042 & 86.1 & 80.2 & 64.6 \\
\hline 4 & 56 & 2.21 & 0.313 & 0.978 & 0.997 & 70.9 & 67.8 & 24.2 \\
\hline 5 & 42 & 2 & 0.347 & 0.988 & 0.977 & 74.8 & 30.7 & 0 \\
\hline 6 & 45 & 3.54 & 0.196 & 0.975 & 1.045 & 92 & 79.4 & 54.9 \\
\hline 7 & 50 & 1.13 & 0.613 & 0.996 & 0.983 & & 61.8 & 0 \\
\hline Mean & & 2.14 & 0.359 & & & 67.9 & 53.8 & 20.9 \\
\hline S.D. & & 0.69 & 0.122 & & & 28.6 & 22.4 & 25.9 \\
\hline
\end{tabular}

' $\mathrm{c}$ and $\mathrm{d}$ are, respectively, the correlation and regression coefficients between the experimental results and the calculated estimates.

${ }^{2}$ Control study performed after about 2 wk course of treatment with prednisone.

${ }^{3}$ The study made during the recurrence phase of the disease.

${ }^{4}$ This patient voided spontaneously $1.5 \mathrm{~h}$ after $\mathrm{F}$ administration. The next time he voided after $3 \mathrm{~h}$.

${ }^{5}$ Statistically different from control at $P<0.05$.

complete absorption of the amount of $\mathrm{F}$ excreted in a $24-\mathrm{h}$ urine collection), as well as for $6 \mathrm{~h}$ after drug administration [the time of diuretic effect of $F(25)]$.

Urinary excretion of $F$. Large intersubject variations were observed in the nephrotic children's $F$ urinary excretion rate measured at $0.5,1$, and $2 \mathrm{~h}$ after $\mathrm{F}$ administration (Table 3 ). However, no significant differences were found between the cumulative $F$ urinary excretion in the nephrotic children and the control children. The 24-h recovery of $F$ in the urine of both patient groups averaged about $50 \%$ of the administered dose.

\section{DISCUSSION}

$F$ absorption. The present study for the first time showed that $F$ administered orally in children with NS is absorbed from the gastrointestinal tract significantly more rapidly than in the control group of patients. Despite the fact that the obtained results were based on model derived calculations (elimination of $\mathrm{F}=$ direct measurements), the reliability of these data is supported by the fact that the maximum urinary excretion rate of $F$ after oral administration in the NS patients occurred within $0-2 \mathrm{~h}$ but only after $1-3 \mathrm{~h}$ in the control children (0-1h: $92.9 \pm 101.2$ (S.D.) $\mu \mathrm{g} /$ $\min , 1-2 \mathrm{~h}: 121.9 \pm 117.9 \mu \mathrm{g} / \mathrm{min}$, and $2-3 \mathrm{~h}: 84.2 \pm 80.7 \mu \mathrm{g} / \mathrm{min}$ vs $0-1 \mathrm{~h}: 30.8 \pm 18.7 \mu \mathrm{g} / \mathrm{min}, 1-2 \mathrm{~h}: 84.7 \pm 65.9 \mu \mathrm{g} / \mathrm{min}, 2-3 \mathrm{~h}$ : $89.2 \pm 46.4 \mu \mathrm{g} / \mathrm{min}$, and $3-4 \mathrm{~h}: 73.1 \pm 22.4 \mu \mathrm{g} / \mathrm{min}$, respectively) (26). These results also were supported by the follow-up studies performed in patients $4 \mathrm{a}, 5 \mathrm{a}, 7 \mathrm{a}$, and $8 \mathrm{a}$, after an approximate 2 wk course of treatment with prednisone $(2 \mathrm{mg} / \mathrm{kg} / \mathrm{day})$ : in those children, the absorption rates of $F$ were found to be slower compared to the respective values obtained in the first investigation. Furthermore, in patient $15 \mathrm{~b}$, who had the relapse of the disease, the absorption rate of $F$ was more rapid than when this patient was in the remission phase. The clinical implication of this finding is rather of no value, but nevertheless it requires explanation which is not easy. It is well known, that the absorption rate of many drugs is proportional to the concentration of their lipidsoluble, unionized form $(6,12,30)$. Gastrointestinal $\mathrm{pH}$, affecting the degree of ionization, may considerably influence the rate of drug transfer (6). F, a weak organic acid with molecular weight of 331 , is highly lipid soluble (the drug partition coefficient in ethyl acetate/buffer pH 3.8 is 32.9) (25), has a pKa of 3.6, therefore is capable of being absorbed from the stomach since in the gastric 


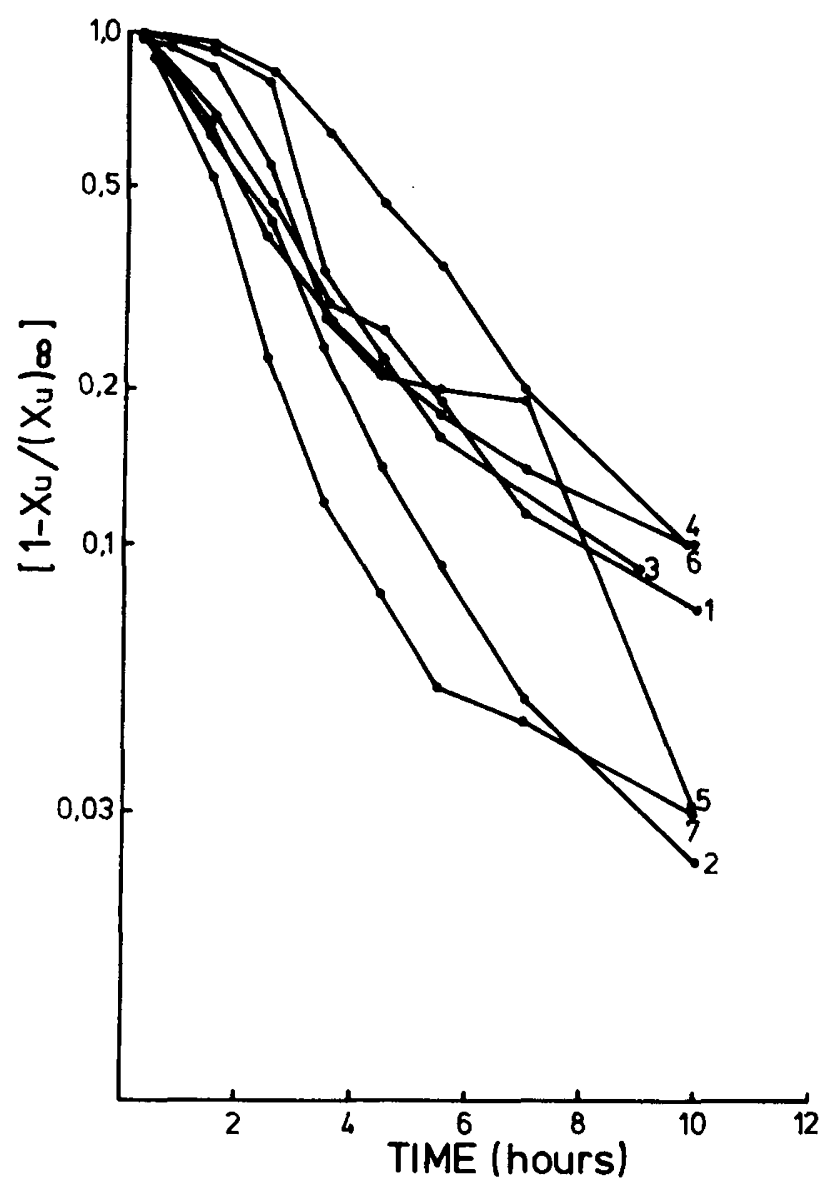

Fig. 2. Semilogarithmic plot of $\left[1-\mathrm{X}_{\mathrm{u}} /\left(\mathrm{X}_{\mathrm{u}}\right)_{\infty}\right]$ versus time as determined from urine data of the control subjects after oral administration of $2 \mathrm{mg} / \mathrm{kg}$ furosemide (further explanation see in the text).

fluid it exists largely in the non-ionic form. Although changes in gastrointestinal $\mathrm{pH}$ are generally known to affect the rate of drug absorption, eventual increases in gastric acidity in the nephrotic children, probably caused by treatment with prednisone/corticosteroids increase hydrochloric acid output and mucosal blood flow (16), showed no effect on the absorption rate of $F$. This was exhibited in patients $4 a, 5 a, 7 a$, and $8 a$, who were shown to have slower drug absorption rates following prednisone therapy than before such treatment.

The results showed no relationship between the serum albumin concentration of the NS patients and the amount of the drug not absorbed one-half or $1 \mathrm{~h}$ after oral administration. There is no information available in the literature concerning the influence of hypoalbuminemia on the absorption rate of drugs. Dayton et al. (4) believe that although binding could be a factor, it probably is not involved in this process.

Finally, it should be emphasized that the urinary elimination half-life of $\mathrm{F}$ and its elimination rate constant were not significantly different between nephrotics and control substance. It is possible that more $F$ is absorbed because the extracellular compartment in an edematous nephrotic is larger providing a greater sink into which the F may move. When it fills up the sink then the rate of removal from the body might be the same in both nephrotics and normals. This speculation is supported by the fact that the volume of distribution of $F$ at steady-state correlates with both serum albumin and drug binding and is increased in the NS patients (28). The slowing down of the absorption rate of $F$ in patients $4 a, 5 a, 7 a$, and $8 \mathrm{a}$, who were in clinical remission of the disease after 2-wk course of treatment with $2 \mathrm{mg} / \mathrm{kg} /$ day dose of prednisone, is in agreement with this speculation. (The opposite effect was observed in patient $15 \mathrm{~b}$, who had the recurrence of the disease).

Bioavailability of $F$ in the NS patients, i.e., the amount of the drug presented to the renal tubule, was found to be about $60 \%$. The same result has been obtained by Kelly et al. (17) in adult healthy volunteers, while Rane et al. (28) has reported $45.5 \pm 8.9 \%$ of the bioavailability of $\mathrm{F}$ in the aduit NS patients. These authors (28), however, like in the present study, did not find statistically significant difference in the bioavailability of $F$ between the adult nephrotics and the control subjects $(45.5 \pm 8.9 \%$ vs $63 \pm 8.9 \%$, respectively). It can be concluded, therefore, that bioavailability of $F$ does not change in the steroid-responsive nephrotic syndrome and is not age-dependent.

Urinary excretion of $F$. In the nephrotic children, the urinary elimination half-life of $F$ averaged $2 \mathrm{~h}$, and was not different compared with the $t 1 / 2$ of $F$ found in the control group of children. The obtained results are in agreement with the plasma half-life of $F$ in adults and children reported by other authors when the period of plasma sampling was longer than a few hours $(3,27$, 30 ). The amount of $F$ which is excreted in urine is however, to a reasonable degree determined by the amount of the drug secreted in the proximal tubule (14). Because $F$ is an organic acid, it is possible that similar compounds may interfere with its tubular transport and diminish rate of secretion in the proximal tubule. This concept has been tested in man with probenecid, and reduction in renal elimination of $F$ was found with only a mild impairment of its diuretic activity $(13,14)$. Concomitant administration of drugs such as penicillin and ampicillin which are secreted in the proximal tubule, in this study, may therefore, effect $F$ secretion (5). The results of our previous investigations performed in infants (26) did not show, however, influence of concomitant administration of ampicillin on the urinary elimination half-life of $F$ in these babies.

Rane et al. (28) have studied $\mathrm{F}$ plasma kinetics in adult patients with nephrotic syndrome after intravenous administration of 80 $\mathrm{mg}$ of the drug. As in the present study they found no difference between $\mathrm{F} \mathrm{t} t^{1 / 2}$ in the nephrotic patients and the control group of subjects. Investigations carried out with another acidic drug, i.e., phenytoin, which is also highly bound to plasma proteins, similarly did not show significant differences in its half-life in nephrotics as compared with controls (10). Similar results have been reported with antipyrine, a drug not substantially bound to plasma proteins (9). On the other hand, the plasma elimination half-life of chlorophenoxyisobutyric acid, an active metabolite of clofibrate, has been determined to be considerably shorter in nephrotic patients $(12.3 \mathrm{~h})$ as compared with control subjects $(21.3 \mathrm{~h})(9)$. It should be pointed out that this metabolite is $96.4 \%$ bound to plasma proteins. Thus, it seems that elimination kinetics of some drugs in nephrotic patients is determined by the physicochemical properties of the drug rather than by its plasma protein binding capacity.

The obtained results showed that it seems to be no relationship between the serum albumin concentration and $F$ elimination halflife in the nephrotic children. This does not mean that $F$ plasma protein binding is not important (in the NS children as compared to normal subjects). As a matter of fact, $t^{1} / 2$ is a consequence of the volume of distribution and the total clearance of the drug: $t^{1 / 2}=0.693 \times V_{d} \times$ clearance $^{-1}$. If both the volume of distribution and the clearance of $\mathrm{F}$ change in the same direction (e.g., because protein binding is altered) there could be a situation where the half-life of the drug would remain unchanged. But data in support of this contention just failed to reach statistical significance in the studies of Rane et al. (28). Also, no correlation was found between the amount of F (mg) excreted in urine during 2 or $6 \mathrm{~h}$ after drug administration and the serum albumim concentration of the patients. Furthermore, the cumulative urinary excretion of $F$ in the nephrotic children was not different compared to that of the control subjects. All these data indicate that despite $F$ high serum albumin binding, factor(s) in addition to serum albumin concentration play a role in the elimination kinetics of $F$ in nephrotic syndrome. 
Table 3. Cumulative excretion of $F$ with urine in nephrotic syndrome patients and control subjects after single oral administration of 2 $\mathrm{mg} / \mathrm{kg}$ dose of the drug

\begin{tabular}{|c|c|c|c|c|c|c|c|c|c|}
\hline \multirow[b]{3}{*}{ Subjects } & \multicolumn{9}{|c|}{ Cumulative $\%$ of $\mathrm{F}$ excreted in urine } \\
\hline & \multicolumn{9}{|c|}{ Time of investigation (hr) } \\
\hline & $0-0.5$ & $0-1$ & $0-2$ & $0-3$ & $0-4$ & $0-5$ & $0-6$ & $0-12$ & $0-24$ \\
\hline \multicolumn{10}{|c|}{ Nephrotic children } \\
\hline 1 & 3.8 & 7.8 & 14.2 & 38.7 & 39.4 & 39.4 & 40.3 & 59.1 & 62.4 \\
\hline 2 & 0.4 & 2.4 & 9.1 & 16.3 & 20.5 & 22.1 & 23.3 & 24.4 & 27.1 \\
\hline 3 & 0.4 & 2.3 & 4 & 5.4 & 10.5 & 12 & 12.4 & 13.8 & 16.8 \\
\hline 4 & 0.8 & 27.8 & 41.4 & 68.8 & & 92.6 & & 97.8 & 107.8 \\
\hline 5 & 3.5 & 9.6 & 12.1 & 14.6 & 15.5 & 15.7 & 16 & 17.3 & 17.7 \\
\hline 6 & & 1.5 & 12 & 19.4 & 23.7 & 28.1 & $31.5^{1}$ & 34.4 & 41 \\
\hline 7 & 0 & 1.4 & 48.2 & 57.2 & 64.6 & 69.8 & 72.6 & & 81.2 \\
\hline 8 & 1.6 & 18 & 21.6 & 38.8 & 52.4 & 55.2 & & 67 & 70.2 \\
\hline 9 & & 0.4 & 1.6 & 3.7 & 5.7 & 6.8 & 8 & 12 & 14.3 \\
\hline 10 & 16.2 & 39.6 & 58.8 & 93.4 & 98 & 104.8 & & & 129.8 \\
\hline 11 & & $2^{2}$ & & 18 & 31.1 & 35 & 36.8 & 40.1 & 41.9 \\
\hline 12 & 10.9 & 26.9 & 53.5 & 61.5 & 71.3 & 72.3 & 73.2 & 75 & 77.3 \\
\hline 13 & 2.6 & 3.6 & 15.2 & 20 & 29.2 & 32 & 35.4 & 48.4 & 62.6 \\
\hline 14 & 4.6 & 21 & 40.2 & 49.4 & 53.4 & & 55.8 & & 59.2 \\
\hline 15 & 0.8 & 3.2 & 12.4 & 20.4 & 25.2 & 28.6 & 31.8 & 36.2 & 39.6 \\
\hline 16 & 1 & 15 & 27 & & 40 & & 42.7 & & 48.9 \\
\hline 17 & 0.8 & 2.4 & 7.6 & & 19 & & 20.2 & & \\
\hline Mean & 1.5 & 10.9 & 23.7 & 35 & 37.5 & 43.9 & 35.7 & 43.8 & 56.1 \\
\hline S.D. & 4.8 & 11.5 & 17.4 & 25.2 & 24.1 & 29.3 & 19.6 & 25.5 & 31.4 \\
\hline $4^{3}$ & 0.6 & 1.2 & 13 & 27 & 34 & 38 & 42.6 & 46.8 & 49.2 \\
\hline $5^{3}$ & 1.8 & 2.6 & 9.3 & 16.4 & 23.6 & 27.6 & 29.7 & 40.8 & 43 \\
\hline $7^{3}$ & 1.4 & 4.8 & 20.4 & 34.8 & 37.8 & 41 & 42.6 & 44.8 & 47.4 \\
\hline $8^{3}$ & 3.4 & 14.7 & 46 & 55.6 & 61.6 & 63.4 & 64.9 & 65.9 & 66.9 \\
\hline $15^{4}$ & 2.2 & 7.1 & 19.6 & 24.4 & 27.3 & 28.9 & 30.2 & 34.7 & 40.8 \\
\hline \multicolumn{10}{|c|}{ Control subjects } \\
\hline 1 & 0.8 & 4.5 & 16.4 & 27 & 35.5 & 37 & 40.5 & 46.1 & 49.8 \\
\hline 2 & 0.1 & 3.7 & 17 & 26.9 & 34.3 & 39.1 & 41.3 & 44.3 & 45.3 \\
\hline 3 & 0 & 1.5 & 3 & 7.4 & 25.3 & 29.4 & 31.8 & 34.7 & 37.9 \\
\hline 4 & 1.6 & 2.6 & 5.5 & 15.3 & 24.7 & 26.7 & 27.8 & 30.7 & 34.1 \\
\hline 5 & 1.6 & 6.4 & 26.8 & 47.7 & 57 & 61.7 & 63.2 & 77.2 & 79.3 \\
\hline 6 & 0.1 & 0.6 & 2 & 6 & 12.6 & 18.8 & 22.9 & 31.1 & 35 \\
\hline 7 & 0 & 7.4 & 30.7 & 56.3 & 59.3 & 60.4 & 60.4 & 62 & 63.8 \\
\hline Mean & 0.6 & 3.8 & 14.5 & 26.7 & 35.5 & 38.7 & 41.1 & 46.5 & 49.3 \\
\hline S.D. & 0.68 & 2.3 & 10.6 & 17.9 & 15.9 & 15.2 & 14.4 & 16.1 & 15.5 \\
\hline
\end{tabular}

${ }^{1.2}$ These patients voided spontaneously 8 and $1.5 \mathrm{~h}$ after $\mathrm{F}$ administration, respectively.

${ }^{3}$ Control study performed after about 2-wk course of treatment with prednisone.

${ }^{4}$ The study made during the recurrence phase of the disease.

\section{REFERENCES AND NOTES}

1. Andreasen, F. and Mikkelsen, E.: Distribution, elimination and effect of furosemide in normal subjects and in patients with heart failure. Eur. J. Clin. Pharmacol., 12: 15 (1977).

2. Aranda, J. V., Perez, J., Sitar, D. S., Collinge, J., Portuguez-Malavasi, A., Duffy, B., and Dupont, C.: Pharmacokinetic disposition and protein binding of furosemide in newborn infants. J. Pediatr., 93: 507 (1978).

3. Beerman, B., Dalén, E., Lindström, B.: Elimination of furosemide in healthy subjects and in those with renal failure. Clin. Pharmacol. Ther., 22: 70 (1977)

4. Dayton, P. G., Israili, Z. H., and Perel, J. M.: Influence of binding on drug metabolism and distribution. Ann. N. Y. Acad. Sci., 226: 172 (1973).

5. Gibaldi, M. and Schwartz, M. A.: Apparent effect of probenecid on the distribution of penicillins in man. Clin. Pharmacol. Ther., 9: 345 (1968)

6. Gibaldi, M.: Introduction to Biopharmaceutics. pp. 3-21, and 64-69 (Lea and Febiger, Philadelphia, Pa., 1971).

7. Gitlin, D.: Immunochemical study of serum albumin in patients with nephrotic syndrome. Am. J. Dis. Child., (Abstract), 83: 82 (1952).

8. Gitlin, D. and Janeway, C. A.: An immunochemical study of the albumins of serum, urine, ascitic fluid and edema fluid in the nephrotic syndrome. J. Clin. Invest., 32: 223 (1952).

9. Gugler, R., Shoeman, D. W., Huffman, D. H., Cohlmia, J. B., and Azarnoff, D. L.: Pharmacokinetics of drugs in patients with the nephrotic syndrome. J. Clin. Invest.. 55: 1182 (1975).

10. Gugler, R. and Azarnoff, D. L.: Drug protein binding and the nephrotic syndrome. Clin. Pharmacokin., 1: 25 (1976).

11. Häussler, R. and Hajdú, P.: Untersuchungen mit dem Salidiureticum 4-chlor- $N$ (2-furylmethyl)-Anthranilsäure (I, II). Arzneimittel-Forsch., 14: 709 (1964).

12. Hogben, C. A. M., Schanker, L. S., Tocco, D. J., and Brodie, B. B.: Absorption of drugs from the stomach. II. The human. J. Pharmacol. Exp. Ther., 120: 540 (1957).
13. Homeida, M., Roberts, C., and Branch, R. A.: Influence of probenecid and spironolactone on furosemide kinetics and dynamics in man. Clin. Pharmacol Ther., 22: 402 (1977)

14. Honari, J., Blair, A. D., and Cutler, R. E.: Effects of probenecid on furosemide kinetics and natriuresis in man. Clin. Pharmacol. Ther., 22: 395 (1977).

15. Houin, G., Thébault, J. J., d'Athis, Ph., Tillement, J. P., and Beaumont, J. L.: A GLC method for estimation of chlorophenoxyisobutyric acid in plasma. Pharmacokinetics of a single oral dose of clofibrate in man. Eur. J. Clin. Pharmacol. 8: 433 (1975).

16. Jacobson, E. D. and Price, W. E.: Effect of hydrocortisone on gastric mucosal blood flow and secretion. Gastroenterology, 57: 36 (1969).

17. Kelly, M. R., Cutler, R. E., Forrey, A. W., and Kimpel, B. M.: Pharmacokinetics of orally administered furosemide. Clin. Pharmacol. Ther., 15: 178 (1974).

18. Lewis, G. P.. Jusko, W. J., Burke, C. W., and Graves, L.: Precnisone side-effects and serum protein levels. Lancet, 2: 778 (1971).

19. Lucas, A., Meignan, M., Le Gall, J. R., Tillement, J. P., and Rapin, M.: Caractéristique pharmacocinétique d'une forte dose de furosemide dans l'insuffisance rénale aiguë. Biomedicine, 24: 45 (1976).

20. Nelson, E.: Kinetics of drug absorption, distribution, metabolism and excretion. J. Pharm. Sci., 50: 181 (1961).

21. Nelson, E. and Schaldemose, 1.: Urinary excretion kinetics for evaluation of drug absorption. I. Solution rate limited and nonsolution rate limited absorption. J. Am. Pharm. Assoc. (Sci. Ed.), 49: 437 (1960).

22. Perez, J., Sitar, D. S., and Ogilvie, R. I.: Kinetic disposition and diuretic effect of frusemide in acute pulmonary oedema. Br. J. Clin. Pharmac., 9: 471 (1980).

23. Prandota, J. and Pruitt, A. W.: Furosemide binding to human albumin and plasma of nephrotic children. Clin. Pharmacol. Ther., 17: 159 (1975).

24. Prandota, J. and Witkowska, M.: Pharmacokinetics and metabolism of furosemide in man. Eur. J. Drug Metab. Pharmacokin., I: 177 (1976).

25. Prandota, J.: Studies on furosemide using rats as an experimental model and in children with different diseases. Summary of the thesis for the degree of docent. 
Pediatr. Pol., 55: 495 (1980)

26. Prandota, J.: manuscript prepared for publication.

27. Pruitt, A. W., Boles, A.: Diuretic effect of furosemide in acute glomerulonephritis. J. Pediatr., 89: 306 (1976).

28. Rane, A., Villeneuve, J. P., Stone, W. J., Nies, A. S., Wilkinson, G. R., and Branch, R. A.: Plasma binding and disposition of furosemide in the nephrotic syndrome and in uremia. Clin. Pharmacol. Ther., 24: 199 (1978).

29. Rubin, M. I.: Nephrotic Syndrome. In: Mitchell I. Rubin, T. Martin Barrat, Eds.: Pediatric Nephrology. pp. 454-484 (The Williams and Wilkins Co., Baltimore. MD., 1975)

30. Rupp, W.: Pharmacokinetics and pharmacodynamics of Lasix. Scot. Med. J., 19: 5 (1974).

31. Schoenemann, P. T., Yesair, D. W., Coffey, J. J., and Bullock, F. J.: Pharmacokinetic consequences of plasma protein binding of drugs. Ann. N.Y. Acad. Sci., 226: 162 (1973)

32. Tillement, J. P., Thébault, J. J., Mattei, C., d'Athis, Ph., and Blatrix, C.: Anticoagulant effect and plasma kinetics of fluorophenindione after a single dose in man. Eur. J. Clin. Pharmacol., 8: 271 (1975).

Copyright (c) 1983 International Pediatric Research Foundation, Inc. 0031-3998/83/1702-0141\$02.00/0
33. Wagner, J. G.: Some possible errors in the plotting and interpretation of semilogarithmic plots of blood level and urinary excretion data. J. Pharm. Sci., 52: 1097 (1963).

34. This paper was presented in part at the 5th Symposium on Clinical Pharmacology, May 28-30, 1980, Pecs, Hungary (Abstracts, p. 60, and 61) and at the World Conference on Clinical Pharmacology and Therapeutics, August 3-9, 1980 , London, England (Abstracts No 0160,0161, and 0176).

35. The author thanks Mrs. A. Banaszak for help in furosemide assays in urine, and Mr. G. Houin from the Department of Pharmacology and Clinical Pharmacology, Faculty of Medicine of Paris XII, Cretéil, France, for calculator-assisted $F$ half-life and elimination rate constant analysis $(15,32)$. The assistance of Prof. J. P. Tillement, Head of the Department of Pharmacology and Clinical Pharmacology, in this study is gratefully acknowledged. Mr. Bruce Hebda gave valuable help with english editing of this manuscript.

36. Reprints not available.

37. Received for publication April 16, 1981.

38. Accepted for publication March 15, 1982. 